\title{
Na margo výzkumu žánru deníku ve slovanském prostředí
}

\author{
Lenka Paučová (Brno)
}

\begin{abstract}
Abstrakt
Deník je v současnosti oblíbeným žánrem spisovatelů i ne-spisovatelů, svědčí o tom vznik množství deníků publikovaných zejména ve druhé polovině 20. a na počátku 21. století. Z perspektivy literární vědy však žánr deníku patř̌ $\mathrm{k}$ těm méně oblíbeným, nevzniká o něm tolik sekundární literatury, jako napřiklad o románu nebo povídce. Předkládaný př́spěvek se zabývá žánrem deníku z hlediska terminologie, jeho místa v systematice autobiografických žánrů. Na př́kladě Deníku spisovatele F. M. Dostojevského a Pod jařmem M. Bulgakova se blíž zaměřuje na žánrový typ spisovatelského deníku a jeho specifikum v kontextu slovanských literatur.
\end{abstract}

\section{Klíčová slova}

autobiografie; žánr a žánrový typ; deník; spisovatelský deník; Dostojevskij; Bulgakov

\section{Abstract \\ On the Research of Genre of a Diary in the Slavonic Environment}

A lot of diaries published in the second half of $20^{\text {th }}$ century and at the beginning of $21^{\text {st }}$ century witnesses about the fact that nowadays, diary is considered to be one of popular genres by writers as well non-writers. From the perspective of literary criticism, diary belongs to less popular genres, because in the recent past about this genre has not been created a lot of secondary literature in comparison with other genres, for example a novel or short story etc. The paper deals with the genre of a diary from the point of terminology, its placement in the systematics of the autobiographical genres. On the example of Dostoyevsky's Diary of a writer and Bulgakov's Under the oppression, the author focuses on the genre type called diary of a writer and its specific features in the context of Slavonic literatures.

\section{Key words}

autobiography; genre and genre type; diary; diary of a writer; Dostoyevsky; Bulgakov

Studie vznikla v rámci projektu Generační konflikt a jeho odraz ve slovanských literaturách, jazycích a kulturách Číslo MUNI/A/0959/2015 podpořeného z prostředkủ účelové podpory na specifický vysokoškolský výzkum v roce 2016. 


\section{Na úvod}

Autobiografické žánry zajímají mezi literárními žánry zvláštní místo, většina z nich se nachází na pomezí; na pomezí beletrie a dokumentární literatury, fikce a nefikce. Svým charakterem tak vytváří skupinu tzv. pomezních žánrů, k níž patří především triáda: deník, memoáry a dopis. Převládající umělecké prvky, obraznost, lyrizace, expresívnost či emocionalita výrazu posouvají uvedené žánry víc k beletrii, když se však jejich dominantou stanou publicistické prvky, dokumentárnost, kontext doby, tyto atributy je přibližují k věcné literatuře.

V souvislosti se vznikem autobiografických žánrů vyslovil ruský literární vědec a dostojevskolog Boris Bursov ${ }^{1}$ zajímavou myšlenku: „Neobyčejný člověk má zřejmě vždy potřebu vyprávět o sobě, nebot' cíti svůj význam. Tak vzniká autobiografický žánr." "2 Vznik autobiografických žánrů Bursov ztotožnil s potřebou výjimečných lidí zanechat po sobě památku, která by se stala svědkem o jejich životě. Uvědomení si svého významu způsobí, že si spisovatelé, filosofové, myslitelé, vědci začnou psát deník, zapisovat své vzpomínky, nebo uchovávat korespondenci. Z pohledu dnešku však musíme konstatovat, že napsat deník, resp. vydat své vzpomínky, může již téměř každý3 a nemusí být přitom ani spisovatelem, tím se ve srovnání například s 19. stoletím hodnota tvůrčí činnosti bohužel snížila.

$\mathrm{V}$ příspěvku se budeme věnovat prvnímu z triády uvedených autobiografických žánrů - žánru deníku. Bude nás zajímat, jaké místo zaujímá deník a jeho žánrový typ spisovatelský deník v systematice autobiografických žánrů, poukážeme na společná a rozdílná místa v oblasti literárněvědní terminologii. Zaměříme se na Dostojevského dílo Deník spisovatele jako na příklad spisovatelského deníku par excellence, přičemž uvedeme další souvislosti, typologické i kontaktové, s deníky spisovatelů ve slovanských literaturách.

\section{Systematika autobiografických žánrů}

Autobiografické žánry vytvářejí složitý systém, slovy Hany Voisine-Jechové „je prakticky nemožné definovat všechny typy autobiografického vyjádřeni", ${ }^{4}$ můžeme však na ně nahlížet na základě míry stylizace.

1 V roce 1974 vyšla monografie Borise Bursova (1905-1997) s názvem Ličnost’ Dostojevskogo (čes. Dostojevskij a jeho svět, 1978), v níž se autor věnoval charakteru ruského spisovatele. Bursov definoval hlavní rysy charakteru F. M. Dostojevského, již se otrážejí v jeho tvorbě, např́íklad ambivalenci v oblasti citů - na jedné straně štědrost, víra v člověka, na straně druhé podezíravost.

2 BURSOV, Boris: Dostojevskij a jeho svět. Praha: Odeon, 1978, s. 11.

3 Pro zajímavost uvádíme např.: MICHELIS de, Camila: Tajný denik. Otevřená zpověd luxusni prostitutky. XYZ, 2011; NACHTIGALLOVÁ, Lucie: Denik fejsbukové matky. Omega, 2016; táže: Deník fejsbukové matky pokračuje. Omega, 2017 a další.

4 VOISINEJJECHOVÁ, Hana: Proměny autobiografických žánrů. Mezi denikem, esejem a narativni fikcí. In: PAVERA, Libor et al: Žánrové metamorfózy v středoevropském kontextu. Praha: Verbum, 2015, s. 30. 
Obrázek 1: Systematika autobiografických žánrů

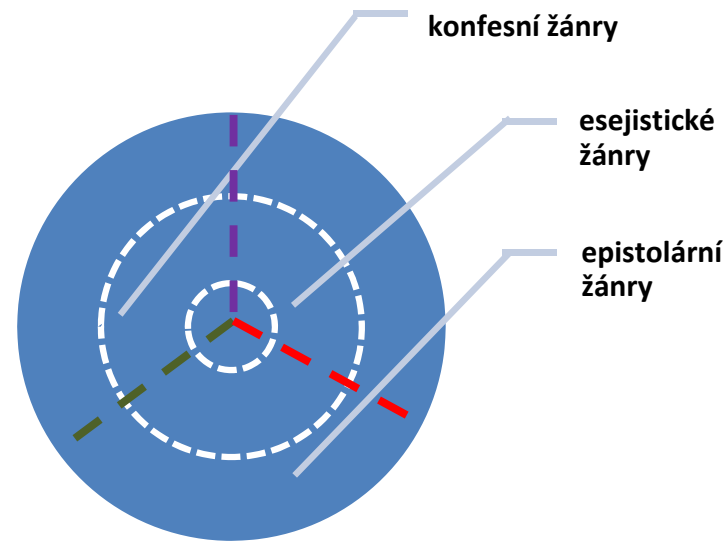

V uvedeném schématu jsme kruh, jenž představuje systematiku autobiografických žánrů, rozdělili na tři části: v rámci autobiografických žánrů jsme tímto způsobem rozlišili symbolickou triádu, tři skupiny žánrů: konfesní, esejistické a epistolární. Hranice mezi nimi jsou otevřeny, protože se tyto skupiny žánrů vzájemně přestupují. V schématu jsme je naznačili přerušovanou čarou.

Obrázek 2: Systematika autobiografických žánrů na základě míry stylizace

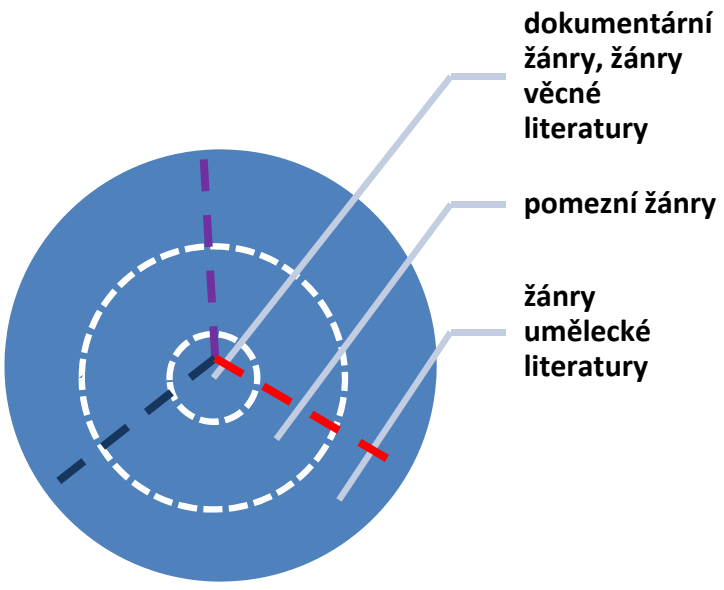

Jak ukazuje naše schéma, v samotném srdci se nacházejí žánry, v nichž je míra stylizace nejmenší, tedy žánry věcné literatury, dokumentární - např. zápisky, poznámky, dopisy. Do dalšího okruhu řadíme žánry pomezní; žánry nacházející se na pomezí beletrie a věcné literatury. $Z$ epistolárních žánrů sem patří např. umělecké listy, z memoárových žánrů memoáry (vzpomínky), v nichž zejména časový odstup způsobuje zkreslení, což 
se následně projevuje v zachycení událostí využitím stylizace. Z konfesních žánrů např̀. deník, především spisovatelský deník, ve kterém opět důležitou roli sehrává stylizace.

Do posledního, třetího okruhu, patří autobiografické žánry s nejvyšší mírou stylizace, jde o žánry umělecké literatury mající autobiografickými rysy - např. autobiografické romány, novely nebo povídky. Jak můžeme vidět, hranice mezi nimi není stálá, právě naopak, může se měnit, proto jsme ji v schématu označili přerušovanou čárou. Do poslední kategorie, v níž se stylizace projevuje nejvíce, bychom mohli řadit také fiktivní deník literární postavy, vystupující častokrát jako žánr v žánru, například Pečorinův deník v románu M. J. Lermontova Hrdina naši doby (Герой нашего времени, 1840), deník Kruciferské z Gercenova románu Kdo je vinen? (Кто виноват?, 1846) nebo deník Tuberozova v románové kronice N. S. Leskova Služebníci sborového chrámu (Соборяне, 1872) a další.

Jaké místo zajímá v systematice autobiografických žánrů deník a jeho žánrový typ spisovatelský deník? Nejblíže ke středu se bude nacházet deník intimní, dokumentární, tedy deník, jenž původně nebyl určen k publikaci. Do střední části bychom umístili spisovatelský deník, typ deníku, který byl primárně určen k publikaci; nejdále od středu již upomínaný fiktivní deník.

\section{Deník versus spisovatelský deník}

Jelikož je deník primárně žánrem epiky, rozhodně nemusí být fixován jenom na epiku. Existuje osobitý typ deníku, tzv. poetický deník, který představuje cyklus básní, řadí se proto k lyrice.

Jak můžeme vidět $\mathrm{v}$ tabulce, $\mathrm{v}$ českém, slovenském a ruském prostředí se setkáváme s obdobnou tendencí: na označení žánrového typu spisovatelského deníku se využívají dva termíny, v češtině - spisovatelský denik, denik spisovatele; ve slovenštině - spisovatelský dennik, dennik spisovatel'a; v ruštině - писательский дневник, дневник писателя. V polském prostředí se však používá jeden termín, konkrétně ekvivalent s neshodným přívlastkem - dziennik pisarza, jenž nejen v polštině, ale i v češtině, ve slovenštině a ruštině asociuje Dostojevského Denikem spisovatele. ${ }^{6}$

V ruském prostředí se na vyjádření žánru a žánrového typu používá stejný termín жанр. Jak se termíny žánr a žánrový typ se prolínají, je vidět v monografii O. G. Jegorova Дневники русских писателей XIX века. Jeho vyjádření působí, jako by spisovatelský deník vyčleňoval jako svébytný žánr. Dodejme, že v ruském prostředí se neujal ani samotný ná-

5 Viz naše studie, v níž jsme srovnávali fiktivní deník v románu M. J. Lermontova Hrdina naši doby a novele J. Hrušovského Muž s protézou: Fiktivni deniky „zbytečných lidi“ v dile M. J. Lermontova aj. Hrušovského. In: POSPÍŠIl, Ivo - ZELENKA, Miloš (eds.): Z dějin literární vědy: metody a přístupy II. Brno: Tribun EU, 2016, s. 63-73.

6 Jelikož má termín deník spisovatele asociace s Dostojevského dílem Deník spisovatele, používáme termín spisovatelský deník. 
zev pro literárněvědnou subdisciplínu, která se literárními žánry zabývá, namísto pojmu генология, se využívá pojem теория жанров, méně жанрология. ${ }^{7}$

Tabulka: Terminologické rozdíly

\begin{tabular}{|c|c|c|c|}
\hline České prostředí & Slovenské prostředí & Polské prostředí & Ruské prostředí \\
\hline rod - epika / lyrika & druh - epika / lyrika & $\begin{array}{l}\text { rodzaj - epika / } \\
\text { liryka }\end{array}$ & род - эпика / лирика \\
\hline žánr (druh) - deník & žáner - denník & gatunek - dziennik & жанр - дневник \\
\hline $\begin{array}{l}\text { žánrový typ - deník } \\
\text { spisovatele, spisova- } \\
\text { telský deník }\end{array}$ & $\begin{array}{l}\text { žánrová forma - den- } \\
\text { ník spisovatela, spiso- } \\
\text { vatel'ský denník }\end{array}$ & $\begin{array}{l}\text { podgatunek - } \\
\text { dziennik pisarza }\end{array}$ & $\begin{array}{l}\text { жанр - писательский } \\
\text { дневник, дневник } \\
\text { писателя }\end{array}$ \\
\hline
\end{tabular}

\section{Specifikum spisovatelského deníku}

Žánrový typ spisovatelského deníku má své charakteristické rysy. Za jeho dominantní rysy považujeme úzké propojení s osobností, ale především s tvorbou daného spisovatele, protože představuje jakoby jeho „tvưrčí dílnu“, 8 s tím související stylizaci a tzv. polymorfní rozpětí (termín I. Pospíšila). ${ }^{9} \mathrm{Z}$ hlediska stylizace můžeme v spisovatelském deníku pozorovat její větší míru než například v intimním deníku, což samozřejmě odkazuje na intenci autora svůj deník později publikovat.

Již zmíněný Boris Bursov nazval F. M. Dostojevského autobiografickým spisovatelem. ${ }^{10}$ Jak jsme již nejednou konstatovali, Dostojevského bychom mohli označit za jednoho z nejautobiografičtějších spisovatelů, protože, i když vzpomínal nerad (jak uváděl - nerad psal listy, proslovy a vzpomínky, protože vzpomínání znamenalo pro něj to samé, co utrpení), je rozpětí autobiografických žánrů v jeho tvorbě velké. Jestli nahlédneme na jeho tvorbu, najdeme v ní deník (publikovaný nejdřív jako součást časopisu Graždanin, pak vydávaný jako samostatné periodikum s názvem Denik spisovatele), poznámky k tvorbě, memoáry (již Dostojevskij integroval do Deniku spisovatele), obsáhlou korespondenci, ${ }^{11}$ eseje (Zimni zápisky o letních dojmech), romány s autobiografickými rysy (Poniženi a uraženi, Zápisky z Mrtvého domu, Bratři Karamazovi a další).

7 Srov. POSPÍŠIL, Ivo: Literárni genologie. Brno: Masarykova univerzita, 2014.

8 V této souvislosti bychm chtěli poukázat na to, že Hana Bočková ve své studii nevymezuje typ spisovatelského deníku, ale deník pracovní a tzv. literární zápisník; tyto žánrové typy mají však k spisovatelskému deníku blízko. Srov. BOČKOVÁ, Hana: K problematice deniku jako literárního žánru. In: Sborník prací Filozofické fakulty brněnské univerzity, D 36-37, 1989-1990, s. 37-45.

9 Termíny polymorfní rozpětí jako vyjádření polygeneričnosti (vícežánrovosti) využívá I. Pospíšil v monografii Rozpětí žánru. Brno: Sprint-Print, 1992.

10 Srov. BURSOV, Boris: Dostojevskij a jeho svět. Praha: Odeon, 1978, s. 11.

11 Korespondence F. M. Dostojevského zahrnuje písemnou komunikaci s rodinnými příslušníky - druhou manželku, Annu Grigorjevnu; starším bratrem Michailem, mladším Andrejem, neteří Sofii Ivanovovou; s přáteli, mezi které patřili například doktor S. D. Janovskij, baron A. J. Wrangel, kritik A. N. Majkov, filozof a básník V. S. Solovjov a další; dále komunikaci se spisovateli, vydavateli, čtenáři, věřiteli a dalšími. 
Z hlediska autorovy osobnosti se do Deniku spisovatele promítá ambivalentní vztah k V. G. Bělinskému, A. I. Gercenovi (Lidé zašlých časů), N. G. Černyševskému (Něco málo o sobě) nebo I. S. Turgeněvovi ( $O$ výstavě), najdeme apologii bratra Michaila (Na obranu mrtvého), vzpomínky na dětství i na káznici. Důkazem polymorfního rozpětí jsou fantastické povídky Bobok, Krokodýl a Sen směšného člověka, novela Krotká, literárněkritické statě (např. Zkormoucená tvář, O novém dramatu), fragmenty vzpomínek (např. Lidé zašlých časů) a další žánry, které Dostojevskij do svého Deniku vložil. Navíc velmi rád naznačoval, o čem bude psát, čemu se bude věnovat, například ve druhé části svého Deniku s názvem Přišti román. Znovu „nahodilá rodina“ Dostojevskij píše, jak rád pozoruje děti, navíc případ vraždy měštanky Perovové ho inspiroval k tomu, aby se vrátil k motivu nahodilé rodiny v dalším románu, doslova o „otcích a dětech“, ze všech společenských vrstev. ${ }^{12}$ Obraz chlapce z části Plody, který se vyžíval v týraní zvířat, asociuje s obrazem Smerd’akova z románu Bratři Karamazovi. V Deniku (Don Carlos a sir Watkin. Znovu př́znaky „počátku konce“) nalezneme doslova citace z románu Výrostek. Snad nejlepším příkladem je část Dvě sebevraždy, v níž Dostojevskij upomíná smrt mladé švadleny Marie Borisovové, která skočila ze střechy s ikonou Bohorodičky v ruce, stala se pak prototypem hrdinky novely Krotká.

Další ruský spisovatel, polyfonií své tvorby srovnatelný s Dostojevským, M. Bulgakov ve svém deníku Spod jarma ${ }^{13}$ píše o těžkém osudu, zdravotních i finančních problémech, o neustálých potížích s cenzurou, dokonce uvádí, jak se jeho rukopisy záměrně ztrácely. ${ }^{14}$ Nejednou se zmiňuje o novele Diaboliáda, o Zápiscích na manžetách, až nakonec ztrácí naději, že by někdy mohly být publikovány a v deníku čteme: „Zápisky na manžetách jsou pohřbeny. "15 V zahraničí přitom patřily díla Bulgakova mezi oblíbené, spisovatel byl často oslovován s nabídkami je přeložit. Na základě deníku se dovídáme další souvislosti s tvorbou spisovatele, například novela Osudná vejce měla podle Bulgakova zkažený konec, protože ji napsal ve spěchu. ${ }^{16}$ Román Bílá garda spisovatel věnoval své druhé manželce Ljubov Jevgenijevně Bělozerské, třetinu románu publikoval v almanachu Rossija, jehož redakce autorova přání zohlednila a v publikovaném textu jeho věnování manželce nakonec zůstalo. ${ }^{17}$

V případě Bulgakova jde o deník subjektivní, intimní; deník, který nebyl primárně určen pro čtenáře, proto se v něm projevuje menší míra stylizace. Z hlediska polymorfního rozpětí se ve srovnání s Dostojevského Denikem spisovatele u Bulgakova setkáváme

12 Srov. DOSTOJEVSKIJ, F. M.: Denik spisovatele I. Praha: Odeon, 1977, s. 194.

13 Michail Bulgakov si svůj deník vedl od roku 1921, v průběhu domové prohlídky 7. 5. 1926 mu však byl zabaven. Spisovatel ho získal zpátky téměř po čtyřech letech, tehdy se za něj přimlouval i Maxim Gorkij. Tyto události na Bulgakova zapůsobily do takové míry, že v psaní svého deníku už nechtěl pokračovat, proto ho v roce 1933 svěřil své manželce Jeleně Sergejevně, která deník vedla až do smrti spisovatele v roce 1940. První část Deniků Mistra a Markétky s názvem Pod jařmem představuje fragmenty z deníku, který si psal Bulgakov, druhou část deníku Román je nutné dokončit napsala jeho třetí manželka Jelena Sergejevna.

14 Např. v redakci časopisu Kopejka se tímto způsobem ztratily jeho fejetony. Srov. BULGAKOV, Michail BULGaKovOVÁ, J. S.: Deniky Mistra a Markétky. Praha: Academia, 2013, s. 26.

15 Tamtéž, s. 34.

16 Tamtéž, s. 44.

17 Tamtéž, s. 54-55. 
jen s náznaky žánrů integrovaných do textu deníku. Jde o krátké žánry, např́iklad glosy a poznámky svým charakterem blízké vtipu.

Uvedené př́klady spisovatelských deníků dokazují propojení tohoto typu deníku s osobností a tvorbou spisovatele; zároveň však vidíme, jak může být autorský přístup v rámci jednoho žánrového typu rozdílný. Větší míra stylizace Dostojevského Deník spisovatele sbližuje s uměleckou literaturou, menší míra stylizace př́tomna v deníku Bulgakova Pod jařmem umožňuje vnímat dílo jako dokument o těžkém osudu spisovatele ve dvacátých a třicátých letech minulého století.

\section{Na závěr}

V příspěvku věnovaném autobiografickým žánrům jsme se zaměřili na žánr deníku a jeho žánrový typ spisovatelský deník. Na základě míry stylizace jsme vytvořili systematiku autobiografických žánrů, přičemž jsme v ní definovali místo deníku a spisovatelského deníku, poukázali jsme na terminologické rozdíly ve slovanském prostředí. Hlavní znaky spisovatelského deníku - propojení s osobností a tvorbou spisovatele, stylizace a polymorfní rozpětí - jsme ukázali na příkladu deníku F. M. Dostojevského a M. Bulgakova.

Myslíme si, že tendence psaní a publikování deníků bude mít i v budoucnu stoupající tendenci; autobiografie, žánr deníku a jeho žánrový typ spisovatelský deník by si však větší pozornost vědců v českém prostředí určitě zasloužily.

\section{Literatura}

BOČKOVÁ, Hana: K problematice deníku jako literárního žánru. In: Sborník prací Filozofické fakulty Brněnské univerzity, D 36-37, 1989-1990, s. 37-45.

BUlGaKOV, Michail - BUlGaKOVOVÁ, J. S.: Deniky Mistra a Markétky. Praha: Academia, 2013. BURSOV, Boris: Dostojevskij a jeho svět. Praha: Odeon, 1978.

DOSTOJEVSKIJ, F. M.: Denik spisovatele I. Praha: Odeon, 1977.

DOSTOJEVSKIJ, F. M.: Denik spisovatele II. Praha: Odeon, 1977.

HLOUŠKOVÁ, Jana: Erupce deniků a memoárů v posledním čtvrtstoletí. Slavia 6, 1994, s. 299-307.

PAUČOVÁ, Lenka: Pisateĺskij dnevnik kak osobyj vid žanra dnevnika v kontekste russkoj literatury.

In: Folia Litteraria Rossica 9. Klasyka rosyjska w przestrzeni kulturowej. Łódź: Wydawnictwo Uniwersytetu Łódzkiego, 2016, s. 23-30.

PAUČOVÁ, Lenka: Fiktioni deniky „zbytečných lidi“ v dîe M. J. Lermontova a J. Hrušovského. In: POSPÍŠIL, Ivo - ZELENKA, Miloš (eds.): Z dějin literární vědy: metody a př́stupy II. Brno: Tribun EU, 2016, s. 63-73.

PAUČOVÁ, Lenka: Žánr spisovatelského deniku u Michaila Bulgakova. Slavica litteraria 18, 2015, č. 2, s. $159-167$.

PAVERA, Libor et al: Žánrové metamorfózy v středoevropském kontextu. Praha: Verbum, 2015.

POSPÍŠIL, Ivo: Literárni genologie. Brno: Masarykova univerzita, 2014.

POSPÍŠIL, Ivo: Rozpěti žánru. Brno: Sprin-Print, 1992. 
VOISINE-JECHOVÁ, Hana: Proměny autobiografických žánrů. Mezi denikem, esejem a narativni fikcí. In: PAVERA, Libor et al: Žánrové metamorfózy v středoevropském kontextu. Praha: Verbum, 2015, s. 28-41.

\section{PaedDr. Lenka Paučová}

Ústav slavistiky

Filozofická fakulta, Masarykova univerzita

Arna Nováka 1, 60200 Brno, Česká republika

440234@mail.muni.cz

Katedra ruského jazyka a literatury

Pedagogická fakulta, Masarykova univerzita

Poříčí 9, 60300 Brno, Česká republika

paucova@ped.muni.cz 